\title{
Tatalaksana Radioterapi pada Kekambuhan Lokal Kanker Ovarium Clear Cell
}

\author{
Rafli, $\mathrm{R}^{1}$ \\ ${ }^{1}$ Bagian Radiologi Fakultas Kedokteran Universitas Baiturrahmah / Instalasi Radioterapi Rumah Sakit \\ Universitas Andalas, Padang, Indonesia. \\ E-mail : rhandykarafli@fk.unbrah.ac.id
}

\begin{abstract}
Abstrak
Latar belakang: Kanker ovarium clear cell merupakan subtype jarang ditemukan. Kanker ovarium tidak memiliki gejala pada stadium awal sehingga lebih sering ditemukan pada stadium lanjut. Tatalaksana standar adalah dengan operasi sitoreduksi dilanjutkan dengan kemoterapi adjuvant Carboplatinum dan paclitaxel. Daya tahan dari sel punca kanker dan sifat kanker ovarium clear cell yang cenderung resisten berperan dalam kekambuhan lokal. Radioterapi dapat berperan secara paliatif untuk mengurangi gejala dan meningkatkan kualitas hidup pasien. Radioterapi dapat diberikan dengan niat kuratif jika relaps terjadi secara lokal, peningkatan dosis dengan brakhiterapi dapat dipertimbangkan sebagai terapi lokal pada residu tumor terbatas. Laporan kasus: Seorang wanita berusia 34 tahun menjalani proses sectio caesarea pada kehamilan pertama aterm. Dalam durante operasi ditemukan massa berbenjol pada ovarium, sehingga diputuskan untuk dilakukan Histerek-Salphingo Oovorektomi Bilateral (HTSOB). Pemeriksaan histopatologi didapatkan jenis tumor adalah kanker ovarium clear cell. Kesimpulan: Radioterapi berperan secara palliative mengurangi gejala perdarahan, nyeri dan memperbaiki kualitas hidup pasien. Pada kanker ovarium clear cells radioterapi diberikan dengan tujuan kuratif dengan target lokal dan dapat diperttimbangkan pada kasus tertentu pemberian brakhiterapi untuk peningkatan dosis.
\end{abstract}

Katakunci — Clear cell carcinoma, kanker ovarium, Radioterapi

\begin{abstract}
Background: Clear Cell Carcinoma is a rare subtype of ovarian cancer. At early stage ovarian cancer were not exhibit symptoms, most of case were found at advanced stage. Treatments for advanced stage ovarian cancer are cytoreduction surgery and carboplatin and paclitaxel adjuvant chemotherapy. Cancer stem cells resilient and chemoresistants phenotype of clear cell carcinoma were responsible for local relapse. Radiotherapy with palliative intents can palleviate symptoms and increase quality of life, radiotherapy can also be given curatively for local relapse. Brachytherapy as dose escalation is recommended for limited and locally tumor residue. Case report: A 34 year old woman underwent cesarean section at her first pregnancy. During the operation, a lumpy mass was found on the ovary, so it was decided to do Hysterical-Salphingo Bilateral Oovorectomy (HTSOB). Histopathological examination revealed that the type of tumor was clear cell ovarian cancer. Conclusion: Radiotherapy plays a role in palliative to reduce symptoms of bleeding, pain and improve the patient's quality of life. In ovarian cancer, clear cell radiotherapy is given for curative purposes with local targets and can be considered in certain cases brachytherapy for increasing doses.
\end{abstract}

Keywords - Clear Cell Carcinoma, Ovarian Cancer, Radiotherapy

Health \& Medical Journal 


\section{Pendahuluan}

Kanker ovarium merupakan 3\% dari kanker yang diderita wanita dan merupakan penyebab kematian ke 2 dari keganasan ginekologi dengan angka kematian sebesar $4,4 \%$ di seluruh dunia ${ }^{1}$. Kanker ovarium pada stadium dini tidak menimbulkan gejala, sehingga sebagian kasus ditemukan pada stadium lanjut dengan angka kematian yang tinggi ${ }^{2}$.

Tatalaksana kanker ovarium berupa operasi sitoreduktif, kemoterapi dan radioterapi. Meskipun dengan tatalaksana yang ada kejadian relaps pada kanker ovarium masih sering ditemui ${ }^{3}$. Kanker ovarium clear cells merupakan varian jarang dari keganasan ovarium dengan paradigma tatalaksana yang belum disepakati $^{4}$

\section{A. Patologi}

Kanker ovarium terdiri dari beberapa subtipe. Kanker ovarium epithelial merupakan patologi terbanyak $(90 \%)$ yang terdiri dari subtipe karsinoma serosa (30$70 \%)$, karsinoma endometroid (10-20\%), karsinoma musinosum $(5-10 \%)$, clear cells $(3-10 \%)$ dan undifferentiated $(1 \%)^{5}$.

Karsinoma clear cells bisa muncul pada ovarium, endometrium dan serviks dan memiliki kemiripan secara biologi dan histologi pada organ tersebut. Secara histologi karsinoma ovarium clear cells juga memiliki banyak kemiripan dengan kanker ginjal clear cells. Meskipun memiliki kemiripan histologi, namun karsinoma clear cells pada organ berbeda memiliki perilaku biologi dan respon pengobatan yang berbeda 6

\section{B. Tatalaksana}

Operasi merupakan tatalaksana utama dalam pengobatan kanker ovarium. Pada stadium dini dilakuakan prosedur surgical staging secara komprehensif, namun pada stadium lanjut dilakukan operasi sitoreduktif dengan mengbuang sebanyak mungkin tumor makroskopis ${ }^{7}$.

Kemoterapi adjuvant diberikan untuk kanker ovarium stadium lanjut dengan kemoterapi berbasis Carboplatinum dan paclitaxel yang diberikan sebanyak 6 siklus, namun pada subtipe kanker ovarium clear cells dikenal memiliki resistensi terhadap kemoterapi dan peran kemoterapi terhadap karsinoma ovarium clear cell perlu ditinjau lebih jauh. 8,9

Paradigma pengobatan kanker cenderung berdasarkan pada lokasi asal tumor. Namun kanker pada lokasi yang sama bisa memiliki patologi berbeda dengan perilaku biologis dan klinis yang berbeda. Tatalaksana kanker berdasarkan lokasi bisa menjadi tidak tepat untuk jenis patologi yang jarang dan berbeda 6.

\section{Peran radioterapi}

Sebelum masa pengobatan kemoterapi berbasis platinum dan taxan, radioterapi abdominopelvis digunakan untuk membersihkan lesi mikrometastasis.

Radiasi abdominopelvis cukup efektif dalam mengatasi kanker ovarium, tetapi memiliki efek samping yang cukup luas sehingga terapi adjuvant dengan carboplatinum dan paclitaxel lebih disukai. Radioterapi untuk kanker ovarium mulai bergeser untuk kasus palliative dan pasien dengan gejala lokal $7,8,10$

\section{Relaps kanker ovarium}

Relaps atau metastasis diperkirakan disebabkan oleh populasi baru kanker yang tumbuh dari sel punca kanker. Sel punca kanker merupakan subpopulasi sel yang memiliki sifat kemo dan radio resisten yang diekspresikan oleh marker seperti aldehyde dehidrogenaase1, efflux drug transporter atau mampu dorman pada fase $\mathrm{G} 0{ }^{11,12}$.

Kemoterapi mereduksi jumlah sel dan mengubah lingkungan mikro tumor menjadi 
Heme, Vol I No 2

July 2019

tidak hipoksia. Keadaan ini akan memicu sel punca kanker yang dorman untuk berproliferasi, dan memicu proses neovaskularisasi ${ }^{13,14}$.

Relaps dapat terjadi pasca pembedahan sitoreduksi atau pada waktu pemberian kemoterapi pada kanker ovarium yang memiliki sifat platinum resisten ${ }^{15,16}$.

\section{LAPORAN KASUS}

Seorang wanita berusia 34 tahun menjalani proses Sectio Caesarea pada kehamilan pertama aterm. Dalam durante operasi ditemukan massa berbenjol pada ovarium, sehingga diputuskan untuk dilakukan Histerek-Salphingo Oovorektomi Bilateral (HTSOB). Pemeriksaan histopatologi didapatkan jenis tumor adalah kanker ovarium clear cell. Pasien selanjutnya menjalani kemoterapi adjuvant Carboplatin dan Paclitaxel sebanyak 6 siklus. 6 bulan pasca kemoterapi siklus terakhir, pasien datang dengan keluhan keluar cairan kemerahan seperti cucian daging dari kemaluan. Dengan jumlah cairan yang semakin lama semakin banyak (maksimal $\pm 500 \mathrm{cc} / \mathrm{hari})$. Pada proses assessment ditemukan pasien mengidap TB paru aktif dan dinyatakan memiliki toleransi yang kurang baik untuk operasi ulang. Pasien dikirim ke instalasi radioterapi untuk tatalaksana paliatif terhadap keluhan perdarahan massif per vaginam.

CT simulasi dilakukan untuk persiapan radiasi paliatif. pada hasil CT simulasi tampak massa yang kambuh pada punctum vagina mengisi ruang pelvis dengan ukuran 1440 cc. Terdapat kelenjar getah bening multiple di iliaka interna. Tidak ditemukan pembesaran kelenjar getah bening para aorta. Eksternal Beam Radio Therapy (EBRT) diberikan dengan Teknik 3dimensional conformal radiotherapy (3DCRT) secara lokoregional dengan dosis 50 Gy dalam 25 fraksi

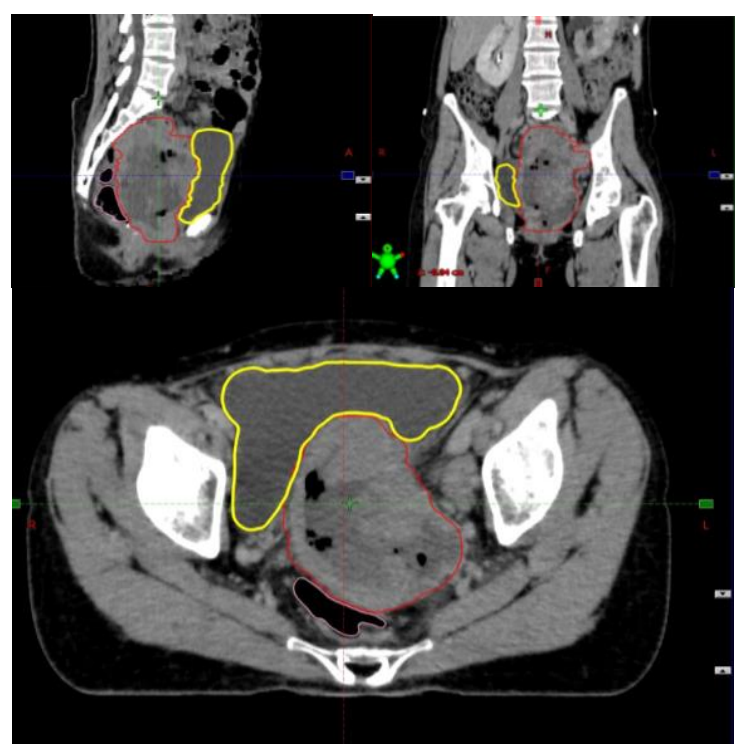

Gambar 1. Gambar Ct simulasi potongan sagittal, koronal dan aksial dengan massa residif pada punctum vagina (garis merah)
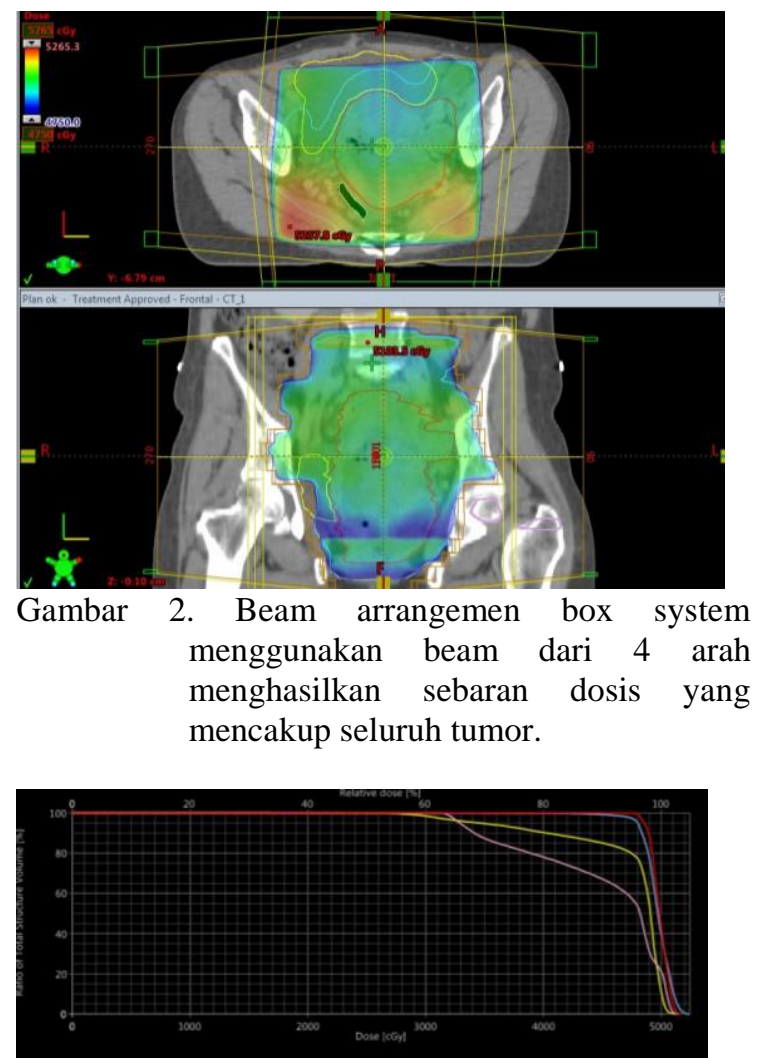

Gambar 3. Dose Volume Histogram (DVH) dimana 95\% dari Planning treatment Volume (biru) mendapatkan 95\% dosis. Dosis buli (kuning) dan rectum (pink) masih dalam toleransi

Perdarahan pervaginam massif menyebabkan anemia berat, sehingga pada minggu pertama dan kedua proses EBRT terjadi beberapa kali 
penundaan radiasi untuk perawatan perbaikan keadaan umum.

Minggu ke tiga sampai ke lima proses EBRT kondisi umum pasien membaik dan perdarahan pervaginam telah berhenti. Setelah pemberian EBRT 50Gy, dilakukan CT simulasi evaluasi. Hasil CT simulasi ditemukan pengecilan massa tumor yang signifikan menjadi $30 \mathrm{cc}$ dan tidak tampak adanya kelenjar getah bening regional.

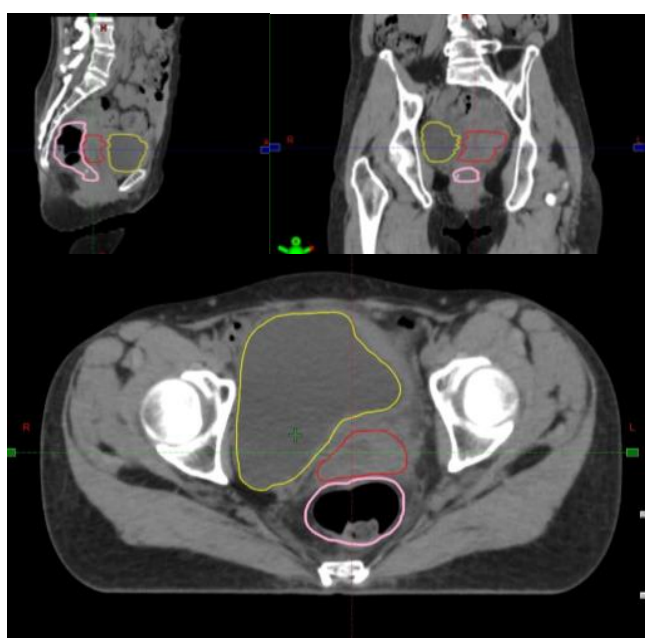

Gambar 4. Hasil CT Evaluasi pasca EBRT ditemukan pengecilan tumor (merah) yang signifikan.

Untuk mengatasi sisa massa tumor pasca EBRT dilakukan Brakhiterapi high Dose Rate menggunakan source iridium-192 dalam anestesi spinal. Karena struktur punctum vaginal yang menyempit dan bentuk massa tumor dengan ulkus yang agak dalam digunakan aplikator fletcher intrakaviter lengkap.

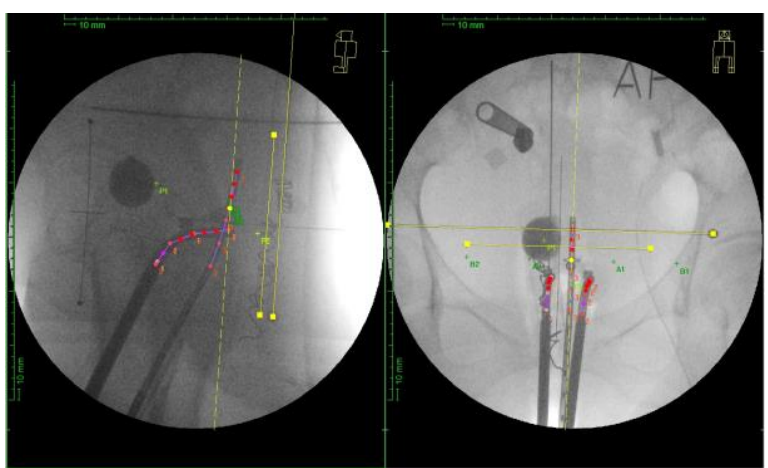

Gambar 5. Brakhiterapi HDR menggunakan aplikator fletcher intrakaviter

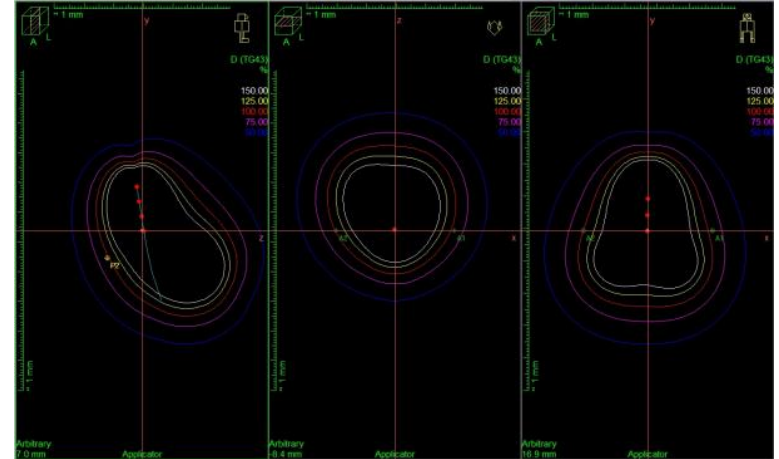

Gambar 6. Planning brakhiterapi HDR dengan preskripsi dosis 21 Gy dalam 3 fraksi pada titik A.

Evaluasi pemeriksaan dalam genitalia pada 2 minggu setelah brakhiterapi HDR fraksi ke 3 tidak ditemukan lagi residu tumor pada punctum vagina. Tampak adanya teleangiektasis dan hiper emis pada $1 / 3$ superior vagina, dan perabaan parametrium kanan dan kiri lemas. Pasien mengalami efek samping sistitis radiasi ringan (grade 1) dan hiperpigmentasi minimal pada kulit pelvis area radiasi.

\section{DISKUSI}

Kanker ovarium clear cell merupakan kasus yang relatif jarang dibandingkan subtipe kanker ovarium lainnya. Pada stadium awal cenderung tidak bergejala. Dimana pada pasien ini ditemukan tidak sengaja pada prosedur sectio caesaria.

Operasi sitoreduksi dengan Teknik histerekoosalphingektomi bilateral kemudian dilanjutkan dengan kemoterapi carboplatinum dan paclitaxel sebanyak 6 siklus merupakan terapi standar untuk kanker ovarium stadium lanjut. Namun subtipe clear cell carcinoma memiliki perbedaan perilaku biologis dengan subtype kanker ovarium lainnya. Belum ada guideline yang spesifik untuk kanker ovarium clear cell $^{7,8}$. Gejala perdarahan massif dan perburukan keadaan umum pasca pemberian kemoterapi 6 siklus diperkirakan karena sifat kemoresisten clear cell carcinoma. 
Pilihan radioterapi sebagai paliatif perdarahan karena radiasi memiliki kemampuan mengobliterasi pembuluh darah kapiler tumor yang mudah berdarah, serta meurunkan sinyal VEGF yang memicu neovaskularisasi ${ }^{17,18}$. Perdarahan diatasi dengan radiasi dan pemberian tranfusi PRC untuk mengatasi anemia yang dapat memperberat hipoksia pada lingkungan mikro tumor ${ }^{13,19}$.

Pemberian radioterapi dengan niat kuratif berdasarkan indikasi lokasi tumor dan kelenjar getah bening yang terbatas lokal serta toleransi pasien yang kurang baik untuk operasi ulang. EBRT diberikan dengan Teknik 3DCRT dengan memberikan dosis besar pada tumor serta menjaga dosis pada organ normal sekitar dibawah ambang toleransi ${ }^{10}$. pemberian radioterapi secara adaptif dengan menyesuaikan perubahan bentuk tumor selama periode EBRT dapat meningkatkan respon pengobatan.

Brachyterapi diberikan sebagai upaya peningkatan dosis pada residu tumor dan bisa mengurangi efek samping radiasi.

\section{KeSimpulan}

Radioterapi berperan secara palliative mengurangi gejala perdarahan, nyeri dan memperbaiki kualitas hidup pasien. Pada kanker ovarium clear cells radioterapi diberikan dengan tujuan kuratif dengan target lokal dan dapat diperttimbangkan pada kasus tertentu pemberian brakhiterapi untuk peningkatan dosis.

\section{Daftar Pustaka}

[1] Bray F, Ferlay J, Soerjomataram I, Siegel RL, Torre LA, Jemal A. Global cancer statistics 2018: GLOBOCAN estimates of incidence and mortality worldwide for 36 cancers in 185 countries. CA Cancer J Clin. 2018;

[2] Das PM, Bast Jr RC, for correspondence A. Early detection of ovarian cancer. Biomarkers Med. 2008;2(3):291-303.

[3] Giornelli GH. Management of relapsed ovarian cancer: a review. Vol. 5, SpringerPlus. 2016. p. 1197.
[4] Shu CA, Zhou Q, Jotwani AR, Iasonos A, Leitao MM, Konner JA, et al. Ovarian clear cell carcinoma, outcomes by stage: the MSK experience. Gynecol Oncol. 2015 Nov;139(2):236-41.

[5] Rosen DG, Yang G, Liu G, Mercado-Uribe I, Chang B, Xiao XS, et al. Ovarian cancer: pathology, biology, and disease models. Front Biosci (Landmark Ed. 2009 Jan 1;14:2089-102.

[6] Glasspool RM, McNeish IA. Clear Cell Carcinoma of Ovary and Uterus. Curr Oncol Rep. 2013 Dec 11;15(6):566-72.

[7] NCCN. Ovarian Cancer Including Fallopian Tube Cancer and Primary Peritoneal Cancer. Clin Pract Guidel. 2017;

[8] Ledermann JA, Raja FA, Fotopoulou C, Gonzalez-Martin A, Colombo N, Sessa C. Newly diagnosed and relapsed epithelial ovarian carcinoma: ESMO Clinical Practice Guidelines for diagnosis, treatment and follow-up. Ann Oncol. 2013 Oct 1;24(suppl 6):vi24-32.

[9] Mabuchi S, Sugiyama T, Kimura T. Clear cell carcinoma of the ovary: molecular insights and future therapeutic perspectives. J Gynecol Oncol. 2016 May;27(3):e31.

[10]Fields EC, McGuire WP, Lin L, Temkin SM. Radiation Treatment in Women with Ovarian Cancer: Past, Present, and Future. Front Oncol. 2017 Aug 21;7:177.

[11] Rafli R, Gondhowiardjo S a, Kantaatmadja AB, Matondang S, Krisnuhoni E. The correlation between aldehyde dehydrogenase-1A1 level and tumor shrinkage after preoperative chemoradiation in locally advanced rectal cancer. Adv Mod Oncol Res. 2015 Dec 2;1(2):112-6.

[12] Patel UB, Brown G, Rutten H, West N, Sebagmontefiore D, Glynne-jones R, et al. The Cancer Stem Cell Marker Aldehyde Dehydrogenase Is Required to Maintain a Drug-Tolerant Tumor Cell Subpopulation. PLoS One. 2013 Oct 4;6(2):464-8.

[13]Rycaj K, Tang DG. Cancer stem cells and radioresistance. Int J Radiat Biol. 2014 Aug ;90(8):615-21.

[14] Mousa L, Salem ME, Mikhail S. Biomarkers of Angiogenesis in Colorectal Cancer. Biomark Cancer. 2015;7(Suppl 1):13-9.

[15] Benish M, Ben-Eliyahu S. Surgery as a doubleedged sword: A clinically feasible approach to overcome the metastasis-promoting effects of surgery by blunting stress and prostaglandin responses. Vol. 2, Cancers. 2010. p. 1929-51.

[16] Pectasides D, Pectasides E, Psyrri A, Economopoulos T. Treatment Issues in Clear Cell Carcinoma of the Ovary: A Different Entity? Oncologist. 2006 Nov 1;11(10):1089-94.

[17] Eleje GU, Eke AC, Igberase GO, Igwegbe AO, Eleje LI. Palliative interventions for controlling 
vaginal bleeding in advanced cervical cancer. Cochrane Database Syst Rev. 2019 Mar 19;

[18] Kondoh C, Shitara K, Nomura M, Takahari D, Ura $\mathrm{T}$, Tachibana $\mathrm{H}$, et al. Efficacy of palliative radiotherapy for gastric bleeding in patients with unresectable advanced gastric cancer: a retrospective cohort study. BMC Palliat Care. 2015 Dec 4;14(1):37.

[19] Kim J, Kim J, Bae J-S. ROS homeostasis and metabolism: a critical liaison for cancer therapy. Exp Mol Med. 2016;48(11):e269. 